\title{
凍土中の不凍水が凍土の圧縮強度に及ぼす影響 \\ THE INFLUENCE OF UNFROZEN WATER ON THE COMPRESSIVE STRENGTH OF FROZEN SOILS
}

\author{
榎戸源則*・鵜 飼恵三**・永瀬英生 $* * *$. 龟田淳二**** \\ By Motonori ENOKIDO, Keizo UGAI, Hideo NAGASE and Junji KAMETA
}

\begin{abstract}
There were few studies on unfrozen water in frozen soils under $0^{\circ} \mathrm{C}$. In order to investigate the relation between unfrozen water and characteristics of frozen soils, unfrozen water contents were measured by the calory metre and calculated by using the specific surface. On Toyoura standard sand and Kaolinite, the measured values were compared with caluculated ones. As the results, it became clear that when the temperature fell the unfrozen water contents decreased and the compressive strength increased.

Keywords: unfrozen water, frozen soil, compressive strength
\end{abstract}

\section{1. まえがき}

最近, 環境公害問題からクリーンエネルギーである低 液液化ガスの地下備蓄や薬液注入に代わる地盤凍結工法 が注目されるに伴い, 土の低温特性に関する研究特に凍 土の強度特性についての研究がなされるようになってき た.しかし, 未凍土の研究に比べると, 凍土の研究はま た緒についたばかりで，その一部分がやっと解明された に過ぎないと思われる。

本報では, $0^{\circ} \mathrm{C}$ 以下の低温になっても一部凍結せずに 凍土中に存在する不凍水について，凍土に及ぼす影響を 明らかにしようとする. 不凍水についての既往の研究は きわめて少ない.これは, 不凍水の測定が困難であり, 労力と費用を要するほどには, 成果の少ない地味な実験 研究であることによると考えられる．しかし，凍土中の 不凍水が凍土の性質特にその強度に重大な影響を及ぼす ことは, 徐々に明らかにされつつある.

* 正会員 工博 群馬大学教授 工学部建設工学科 （テ376 桐生市天神町 1-5-1)

** 正会員 工博 群馬大学助教授 工学部建設工学科 (同上)

*** 正会員 工博 群馬大学助手 工学部建設工学科 (同上)

**** 学生会員 群馬大学大学院工学研究科建設工学専攻 (同上)
不凍水は温度低下とともに減少する，ここでは, 豊浦 標準砂とカオリンについて, 熱量計による直接測定結果 と比表面積による間接的計算結果とを比較し, 温度およ び一軸圧縮強度との関係を比較検討した。

なお, 本研究は昭和 $59 \cdot 60$ 年度文部省科学研究費補 助金（一般研究（B）59460140）により実施された一連 の研究の一部であり，低温土質工学研究への端緒を与え ていただいたことを深く感謝申し上げる.

\section{2. 実験方法および不凍水の測定・計算結果}

供試体の作製方法は次のように行う，標準砂は，所定 の型枠 (円柱形 $5 \phi \times 10 \mathrm{~cm})$ に水と砂とを少量ずつ入 れ突き固めと振動を与えながら充填する. カオリンは $420 \mu \mathrm{m}$ のふるいを通過させた後, 所定の含水比になる よう蒸留水を加え, ミキサーで練り返したものを予備圧 密槽に入れ, 両面排水で約 72 時間, 圧力 $4 \mathrm{kgf} / \mathrm{cm}^{2}$ で 圧密し, 整形した後型枠に入れビニール袋で密封する. これらの試料をフリーザー $\left(-100^{\circ} \mathrm{C}\right.$ まで冷却可能 $) に$ 入れ，所定の温度まで急速凍結した ${ }^{3)}$.

\section{（1）熱量計による不凍水の測定}

熱量計法は土の熱的諸性質を測定するための信頼性の 高い方法である. 凍土の試料を熱量計液（水）の中に入 れ温度を測定する. 用いられた装置は断熱された容器, 
摫汼器などであり, 特に熱量計として, 低温断熱性のよ い特殊の容器（デュワー瓶）を使用したので, その信頼 性は高いと思われる．凍土中の水がすべて凍結している とすれば，その水分に相当する熱量を熱量計から吸収す るはずである，しかし，実際には，それより少ない熱量 しか吸収されない，これは，凍土中の水がすべて凍結し ておらず，凍土中に未凍結の水すなわち不凍水が存在し ているからであるとみられる。 そこで，凍土を熱量計内 で融解させたときの温度変化を測定することにより, 熱 の出入から不凍水量を求める.

熱量計が温度低下によって失った熱量 $Q_{1}$ は, 水の比 熱を 1 とすると

$$
Q_{1}=\left(M_{1}+W\right)\left(T_{1}-T_{f}\right)
$$

土粒子が温度上昇によって得た熱量 $Q_{2}$ は，

$$
Q_{2}=M_{2} \cdot C_{2}\left(\left|T_{0}\right|+T_{\jmath}\right)
$$

不凍水が温度上昇によって得た熱量 $Q_{3}$ は,

$$
Q_{3}=\left(M-M_{2}-M_{3}\right)\left(\left|T_{0}\right|+T_{f}\right)
$$

水が温度上昇によって水になり, 平衡温度に達するまで に得た熱量 $Q_{4}$ は，

$$
Q_{4}=M_{3}\left(C_{3} \cdot\left|T_{0}\right|+79.7+T_{f}\right)
$$

以上の熱の収支は $Q_{1}=Q_{2}+Q_{3}+Q_{4}$ となる. すなわち

$$
\begin{aligned}
\left(M_{1}+W\right)\left(T_{1}-T_{f}\right)= & M_{2} \cdot C_{2}\left(\left|T_{0}\right|+T_{f}\right)+\left(M-M_{2}-M_{3}\right) \\
& \cdot\left(\left|T_{0}\right|+T_{f}\right)+M_{3}\left(C_{3} \cdot\left|T_{0}\right|\right. \\
& \left.+79.7+T_{f}\right)
\end{aligned}
$$

ゆえに

$$
M_{3}=\frac{\left(M_{1}+W\right)\left(T_{1}-T_{f}\right)-\left\{M+M_{2}\left(C_{2}-1\right)\right\}\left(\left|T_{0}\right|+T_{f}\right)}{79.7+\left(C_{3}-1\right)\left|T_{0}\right|}
$$

ここに, $M$ : 試料質量 $(\mathrm{g}), M_{1}:$ 水の質量 $(\mathrm{g})$,

$M_{2}:$ 試料の土粒子質量 $(\mathrm{g})$,

$M_{3}$ : 試料の水の質量 $(\mathrm{g})$,

$M_{4}$ : 試料の不凍水質量 $(\mathrm{g})$,

$C_{2}$ : 乾燥土の比熱 $\left(\mathrm{cal} / \mathrm{g} \cdot{ }^{\circ} \mathrm{C}\right)$,

$C_{3}$ : 水の比熱 $\left(0.475 \mathrm{cal} / \mathrm{g} \cdot{ }^{\circ} \mathrm{C}\right)$,

$T_{0}$ : 試料温度 $\left({ }^{\circ} \mathrm{C}\right), T_{1}$ : 水の温度 $\left({ }^{\circ} \mathrm{C}\right)$,

$T_{s}:$ 混合後の温度 $\left({ }^{\circ} \mathrm{C}\right)$,

$W:$ 熱量計の熱容量 $\left(\mathrm{cal} /{ }^{\circ} \mathrm{C}\right)$, 水の潜熱 $=79.7(\mathrm{cal} / \mathrm{g})$

\section{これから不凍水量は}

$$
M_{4}=M-M_{2}-M_{3}
$$

となる.ここで, 熱量計の熱容量は, あらかじめ熱した 銅線を熱量計に投入し,平衡後の温度を測ることにより， 同じように求められる.

$$
W=\frac{M_{c} \cdot C_{c}\left(T_{0}-T_{f}\right)-2000\left(T_{f}-T_{1}\right)}{T_{f}-T_{1}} .
$$

ここに, $M_{c}$ : 銅線の質量 $(\mathrm{g}), C_{c}$ : 銅の比熱 $\left(\mathrm{cal} / \mathrm{g} \cdot{ }^{\circ} \mathrm{C}\right)$, $T_{0}$ : 銅線の温度, $T_{1}$ : 水温, $T_{f}$ : 混合後の温度

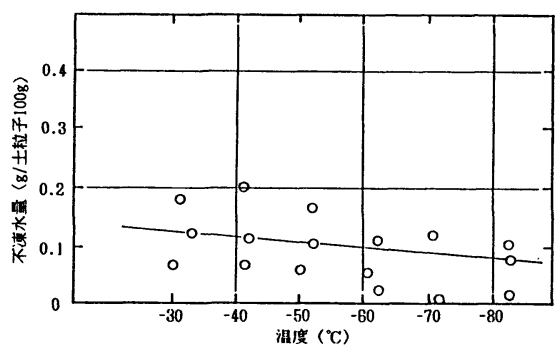

图一1＼cjkstart標準砂の不凍水量と温度（熱量計による）

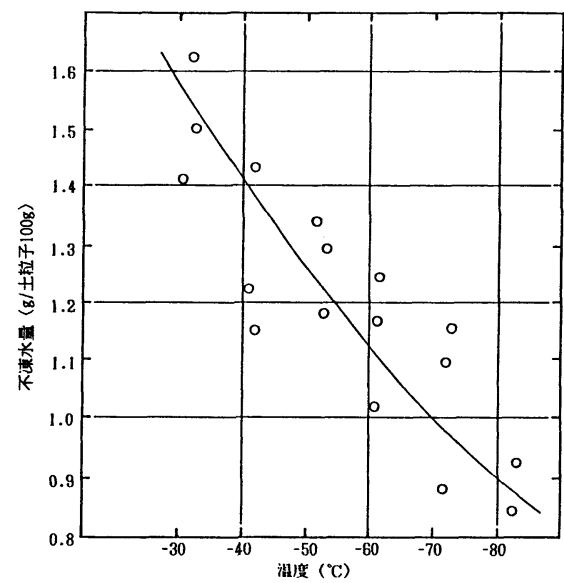

図一2 カオリンの不凍水量と温度（熱量計による）

なお，標準砂とカオリンの比熱を求めた結果は，それ ぞれ $0.230\left(\mathrm{cal} / \mathrm{g} \cdot{ }^{\circ} \mathrm{C}\right)$ と $0.129\left(\mathrm{cal} / \mathrm{g} \cdot{ }^{\circ} \mathrm{C}\right)$ の值となっ た.

このようにして, $-30^{\circ} \mathrm{C} \sim-80^{\circ} \mathrm{C}$ における標準砂と カオリンの不凍水量を測定した結果を図一1，図一2に 示す.

\section{（2）比表面積による不凍水量の計算}

試料単位質量中に含まれる土粒子の表面積を比表面積 $S\left(\mathrm{~m}^{2} / \mathrm{g}\right)$ という. 比表面積から間接的に不凍水量を求 めるには, Anderson および Dillon の実験式を用いる.

比表面積の測定法としては，Brunauer，Emmettおよ びTellerによって開発されたBET 法を用いた。 BET 法とは吸着ガス（本実験では窒素ガス）を粒子表面に吸 着させ, 単分子層を形成するに要した量 $V_{m}($ mole ) お よび吸着分子 1 個の占有面積 $\sigma$ から比表面積 $S$ は,

$S=\sigma \times V_{m} \times 6.02 \times 10^{23}$

により求められる.この結果，標準砂およびカオリンの 比表面積は，それぞれ $0.31\left(\mathrm{~m}^{2} / \mathrm{g}\right)$ および $18.51\left(\mathrm{~m}^{2} / \mathrm{g}\right)$ の值が得られた。これらの値を用いて, 不凍水分量を計 算する.
a) Anderson の実験式による方法1)
$\ln W_{u}=0.2618+0.5519 \ln S$ 


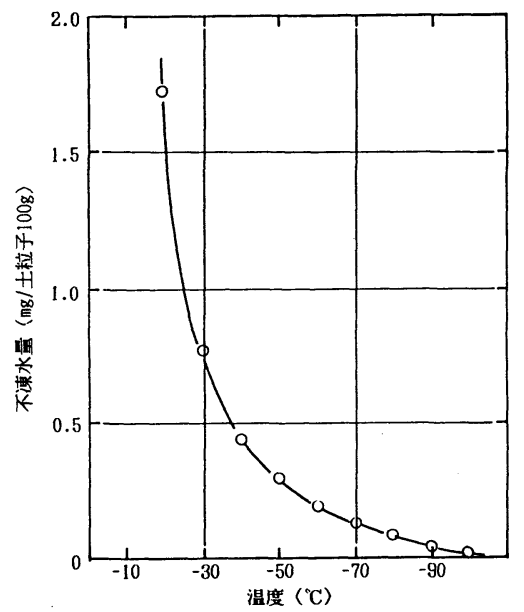

図一3 標準砂の不凍水量と温度 (Anderson の式)

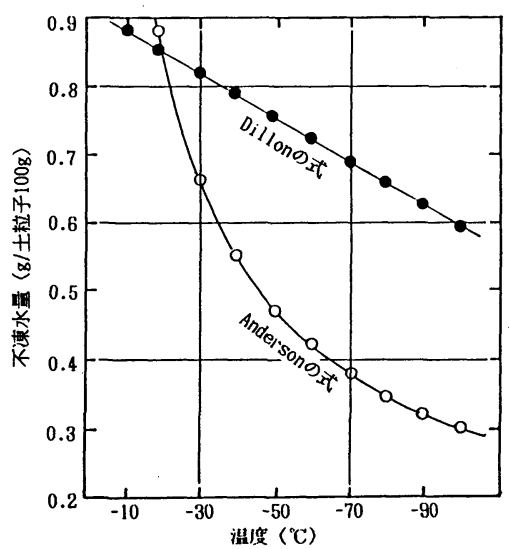

図一4 カオリンの不凍水年と温度（比表面積による）

$-1.4495 S^{-0.264} \ln \theta$

ここに,

$W_{u}$ : 不凍水分比（土粒子 $100 \mathrm{~g}$ 当たり不凍水量 $\mathrm{g} / 100 \mathrm{~g} \cdot \mathrm{soil})$

$S:$ 比表面積 $\left(\mathrm{m}^{2} / \mathrm{g}\right)$

$\theta:$ 凍土の温度 $\left({ }^{\circ} \mathrm{C}\right)$

上式により土の比表面積と温度から不凍水量を求める.

b) Dillon の実験式による方法 ${ }^{21}$

Dillon らは, 比表面積と温度, 活性度等から不凍水 量を算定する次式を提案した.

$$
W_{u}=\frac{S \cdot T}{T_{0} \cdot A_{c}} l \times 2.8 \times 10^{-2}
$$

ただし，

$W_{u}$ : 不凍水分比（土粒子 $100 \mathrm{~g}$ 当たりの不凍水 量 $\mathrm{g} / 100 \mathrm{~g} \cdot$ soil $)$

$S:$ 比表面積 $\left(\mathrm{m}^{2} / \mathrm{g}\right)$

$T:$ 凍土の温度 $\left({ }^{\circ} \mathrm{K}\right), T_{0}:$ 水点 $\left({ }^{\circ} \mathrm{K}\right)$

$A_{c}$ : 土の活性度 $\left(=I_{\rho} / \%<2 \mu, I_{\rho}\right.$ : 塑性指数 $)$ $l:$ 定数（比膨潤性粘土 1, 膨潤性粘土 2$)$

これらの計算結果と温度との関係を図一3および図一 4 に示す.

図一3 は標準砂の場合, 図一4は, カオリンの場合で ある. Dillon の実験式は活性度 $A_{c}$ の值を必要とするが, 標準砂については活性度は求められなかったので, 力オ リンについてのみ求めた. なお, カオリンの活性度 $A_{c}$ $=0.57$ であった.

\section{3. 考察}

以上の不凍水量の測定結果について, 主として温度お よび一軸圧縮強度との関係から検討を加える.

\section{（1）不凍水量と温度との関係}

熱量計により測定された不凍水量は，図一1および図 一2 から明らかなように, 標準砂の場合, 温度が降下し てもさしたる減少の傾向を示さず，ほぼ一定値をとるか にみえる. しかし, カオリンの不凍水量は, 温度低下と ともに明らかに減少していることがわかる。

図一3，図一4の比表面積によるAndersonまたは Dillon の実験式からの計算値を検討すると, 標準砂の 場合, 熱量計による測定値（図一1）よりかなり小さな 值となっているが, 温度低下による減少の傾向は, 明ら かに示されている. カオリンについては, Andersonの 式による值と Dillonの式による值とも, 曲線と直線の 相違はあるが, 温度低下とともに不凍水量は減少してい る. しかし, 熱量計による測定值（図一2）に比へ，小 さい值となっている. このように, それぞれの測定值や 計算值にかなりのばらつきがあり，いずれの值を真実の 值とするか判断しがたいが，カオリンについては，2つ の計算結果が比較的近似しており, BET 法による比表 面積の測定法も信頼性が高いこと等を考慮すると, 温度 低下とともに不凍水量は減少するといえよう.

標準砂については, 熱量計による測定值（図一1）と Anderson の実験式による計算値（図一2）が 2 析程度 異なっている.この原因として，(1)比表面積による Anderson の実験式は，粘性土について適合し，砂には 適用できないのではないか.これは，カオリンの比表面 積が $18.51\left(\mathrm{~m}^{2} / \mathrm{g}\right)$ であるのに対し，標準砂が僅か $0.31\left(\mathrm{~m}^{2} / \mathrm{g}\right)$ であり, Anderson 式の適用範囲として, 比表面積 $S$ が， $0.02 \leqq S \leqq 800$ とされてはいるが4), 原 文 ${ }^{1)}$ では $\theta \sim W_{u}$ の関係として, $\theta \geqq-10^{\circ} \mathrm{C}, 5 \leqq S \leqq$ 1000 の範囲が明記されているので, 砂には適用されない ことがわかる.(2)標準砂の不凍水がきわめて小さいため, 熱量計による測定が困難であること．以上 2 点が考えら れる. しかし, 不凍水の測定は, その絶対量より相対量 が問題であるとするならば，测定値・計算値とも，不凍 水量は温度低下とともに減少する傾向を示しているとい 


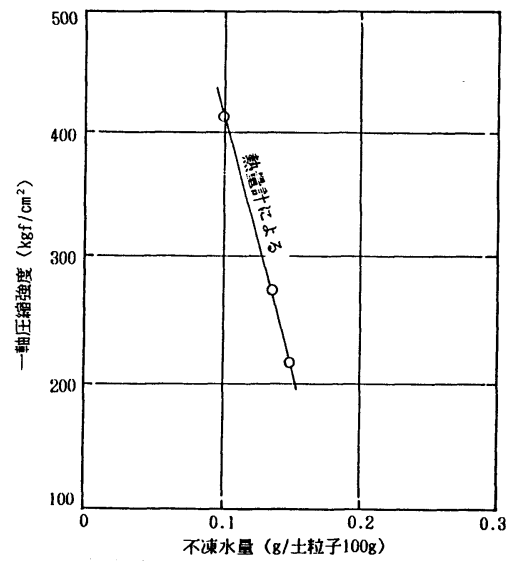

図一5 標準砂の一軸圧縮強度と不凍水量

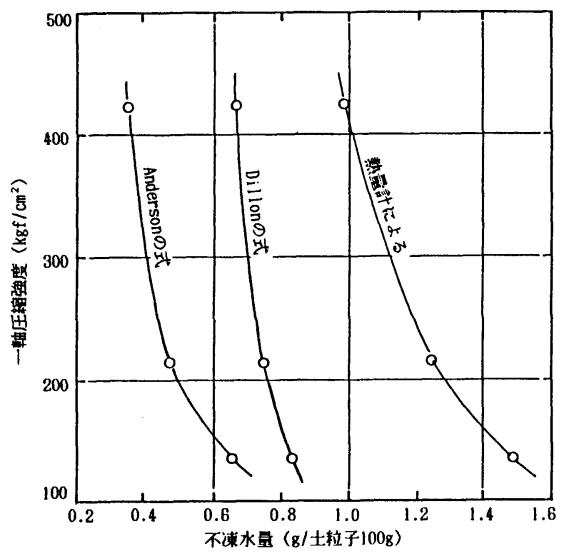

図一6 カオリンの一軸圧縮強度と不凍水量

える.

また, Anderson 式は $-10^{\circ} \mathrm{C}$ 以上 ${ }^{1)}$, Dillon式は一 $20^{\circ} \mathrm{C}$ 以上 ${ }^{2)}$ の低温域について求められたものであるが, カオリンについては, $-20^{\circ} \mathrm{C}$ 以下の低温でも適用性が あるとみられる。

\section{（2）不凍水量と一軸圧縮強度との関係}

（1）で述べた不凍水量と温度との関係を一軸圧縮強 度と温度との関係 ${ }^{3}$ と結びつけ, 不凍水量と一軸圧縮強 度との関係を求めると, 図一 5 , 図一6のような関係が 得られる. 標準砂, カオリンとも不凍水量が減少すると, 一軸圧縮強度は増加している.この結果加, 温度低下

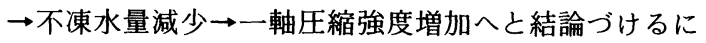
は, さらに研究・検討を必要としても, 水の圧縮強度は 10 30 kgf/ $\mathrm{cm}^{2}$ と非常に小さいので ${ }^{5)}$, 不凍水量が一軸 圧縮強度にかなりの影響を与える因子の 1 つであるとは いえそうである.

また, 高志らの「不凍水量が同じなら, 砂凍土と粘土

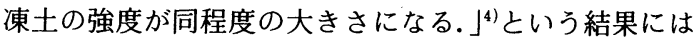

ならないようにみえる，図一 5 と図一6からは，「同強度 の砂凍土の不凍水量は粘土凍土の不凍水量より小さい.」 という結果が得られており, 本研究の結果からは, 「不 凍水量が同じ場合，砂凍土より粘土凍土の強度が大きく なる.」と推定されるからである.

\section{4. むすび}

本研究では $-20^{\circ} \mathrm{C}$ 以下の低温域について, 不凍水量 と圧縮強度との関係について検討した結果, 次のような 結論が得られた。

（1）凍土（標準砂, カオリン）の不凍水量は, 温度 低下とともに減少する.

（2）不凍水量の減少に伴い，一軸圧縮強度は増加す る傾向がみられる.

（3）比表面積から不凍水量を求める Anderson およ び Dillon の実験式は, 粘土（カオリン）については適 合するが，砂（標準砂）については，良好な適合性はみ られない。したがって，これらの式は粘土についての実 験式である.

（4）これらの不凍水の算定式は, 不凍水の絶対的値 よりも，温度との相対的な值を示す。

(5) これらの式は, $-20^{\circ} \mathrm{C}$ 以下の低温域について も，ある程度の適合性が認められる. 不凍水について， 今後一層の実験研究が必要とされると思われる.

なお，不凍水の測定にあたっては，応用地質（株）大 井部長のご教示を受け, 比表面積の測定には, 本学合成 化学科大谷研究室のご援助を受けた. 深く感謝申し上げ る.

実験に協力していただいた群馬大学学生 松本 伸君 （現・高崎市役所）を始め，土質研究室の諸君に謝意を 表する.

\section{参 考 文 献}

1) Anderson, D.M. and Tice, A.R. : Predicting unfrozen water contents in frozen soils from surface area measurements, U.S. Army Cold Regions Research and Eng. Laboratory, Highway Research, Record, No. 393, pp. 12 18, 1972.

2) Dillon, H.B. and Andersland, O.B. : Predicting unfrozen water contents in frozen soils, Canadian Geotechnical Journal, Vol. III, No.2, pp. 53 60, May 1966.

3）榎戸ほか： $-30^{\circ} \mathrm{C} \sim-70^{\circ} \mathrm{C}$ における凍土の一軸圧縮強度 特性, 土木学会第 40 回年次学術講演会概要集, 1985.

4）高志ほか：均質な粘土凍土の一軸圧縮強度に関する実験 的研究, 土木学会論文報告集, 第 315 号, pp. 83 93, 1981 年 11 月.

5）木下誠一：凍土の物理学, 森北出版, p. 11, 1982.

(1986.5.8 - 受付) 